\title{
Three Decades of Review on Existing Agroforestry Systems and Practices in South Gujarat
}

\author{
H. K. Deshmukh*, M. B. Tandel, R. P. Gunaga, N. S. Thakur, M. J. Dobriyal, \\ Narendra Singh, H. N. Chhatrola and R. J. Mevada \\ College of Forestry, Navsari Agricultural University, Navsari-396 450, Gujarat, India \\ *Corresponding author
}

\section{A B S T R A C T}

Keywords

Agroforestry systems,

Classification,

South Gujarat,

Agro climatic zone

Article Info

Accepted:

24 July 2020

Available Online:

10 August 2020
The aim of this study was to review the work done by various researchers on the existing agroforestry systems in Gujarat particularly South Gujarat. The secondary data sources were used to study and examine like books, research articles, review articles and findings of case studies done earlier. The research articles published during 1991 to 2019 were selected for the review purpose. It was observed that researchers classified the agroforestry systems based on nature and arrangement of the components. Many researchers and scientists reported minimum two and maximum six agroforestry systems adopted by farmers in Gujarat as well as South Gujarat.

\section{Introduction}

Agroforestry is not a new system or concept (Dwivedi, 2015) but traditionally been a way of life and livelihood in India from centuries (Dhyani, 2013). Growing of trees with food crops, grasses and other components (Nair, 1985) is believed to have started during ancient era, however agroforestry as science evolved in recent years (Dhyani, 2013). The widely accepted definition of agroforestry is "Agroforestry is a collective name for land use system in which woody perennials (tree, shrubs etc.) are grown in association with herbaceous plants (crops, pastures) or livestock, in spatial arrangement, a rotation or both; there are usually both ecological and economic interactions between the trees and other components of the system" (Lundgren, 1982). Looking to the importance of the agroforestry, India became the first country in the world who adopted special policy on agroforestry called 'National Agroforestry Policy', enacted in 2014. According to the NAFP (2014), 'Agroforestry is defined as a land use system which integrates trees and shrubs on farmlands and rural landscapes to enhance productivity, profitability, diversity 
and ecosystem sustainability. It is a dynamic, ecologically based, natural resource management system that, through integration of woody perennials on farms and in the agricultural landscape, diversifies and sustains production and builds social institutions. Based on three major components namely tree, crops and pasture/animals (Nair, 1985), structurally the agroforestry systems can be grouped into five major categories namely Agri silviculture systems, Agri horticulture system, silvipastoral system, agri-silvipastoral and other or specialized systems. Further Nair (1993) categorized agroforestry systems on four main criteria namely i) structural basis (based on nature and arrangement of components), ii) functional basis (productive function and protective function), iii) ecological basis (based on agroecological situation) and iv) socio-economic basis (commercial, intermediate and subsistence level). However According to Cooper et al., (1996) agroforestry systems have been classified into two groups, namely sequential and simultaneous.

\section{Overview of agroforestry in India}

As per State Forest Report (2013) the total area under agroforestry of the country is 3.39 per cent, whereas, out of total geographical area of Gujarat $(196,022 \mathrm{Sq} . \mathrm{km})$, the area under agroforestry is 5.91 percent which is second highest in the country. At present agroforestry meets near about $50 \%$ of the demand of fuel wood, $34 \%$ of the small timber, 70-80\% of wood for plywood, $60 \%$ of raw material for paper pulp and 9-11 per cent of the green fodder requirement of livestock, besides meeting the subsistence needs of households for food, fruit, fiber, medicine etc. (Dhyani, 2013). It is also realized that agroforestry is the only alternative to meet the target of increasing forest cover to 33 per cent from the present level of less than 25 per cent (NAFP, 2014).
In India, agro forestry practice is extensively done in traditional as well as modern form in many states especially in northern region like Punjab, Haryana, Uttarakhand, Uttar Pradesh etc. (Dhyani, 2013). Agroforestry is economically, environmentally and socially important for rural people of India. India has only 0.064 ha of forest area per capita as against 0.64 ha of world average and the forest policy also aims at improved productivity to meet both local and national needs (Mukherjee, 2011). Dhyani (2013) reported that in general there are five basic sets of components which are managed in all agroforestry system in Indian and structurally, the system can be grouped as Agrisilviculture system, Agrihorticulture system, Silvipastoral system, Agri-silvipastoral system and Other or specialized systems. Further, total 20 common agroforestry systems were reported by Dhyani (2013) found in different agroecological regions of India.

\section{Agroforestry systems and practices in Gujarat}

Gujarat is one of India's most prosperous states, having an agricultural based economy. The total forest cover in Gujarat is $7.5 \%$, which is relatively low comparing to country's forest cover $(21.67 \%)$, whereas, the trees outside forest (TOF) constitutes about $3.52 \%$ of the total geographical area of the state (ISFR, 2019). Out of total area under TOF, $71.3 \%$ were on private land particularly under agroforestry. The growing stock of the TOF in Gujarat is 118.00 million cubic meter against only 48.3 million cubic meter in the forest area in the state, indicating the importance of tree resources outside forest land (Singh, 2017).

Verma (1990) observed that nine out of ten farmers raised eucalyptus either in pure stands or in combination with other tree species, however other trees have not found very 
much favour among farmers however, the peripheral and mixed planting are both popular all over the Gujarat State, but agroforestry tends to be marginally more accepted under irrigated than rainfed conditions (Verma, 1991). Whereas in south eastern part of Gujarat, the farmers adopted various agroforestry systems according to their needs to achieve livelihood security, which may raising the opportunities of diversification and climate resilience (Singh, 2017).

Few researchers had reported various agroforestry systems in Gujarat as well as South Gujarat, the details are given in tabular form in Table 1.

Jharna Pathak (2011) revealed that the most prevalent agroforestry systems adopted by farmers were fruit-based agroforestry systems, where the farmers adopted alley cropping, homegardens and windbreaks. This fruit based agroforestry model promoted by NGO-BAIF in tribal area of Gujarat is popularly known as 'wadi'. Bhatt et al., (2013) studied the vegetation types in South Gujarat using remote sensing and GIS.

They found that main vegetation types of south Gujarat included teak mixed dry and moist deciduous forest, mangrove forest, mangrove scrub, riverain forest, ravine thorn forest, forest plantation, degraded forest, scrub, Prosopis juliflora, grassland and orchard. Singh (2013) revealed that the main species found on farmland were Teak, Eucalyptus, Mango, Desi babool, Neem, Casuarina, Bengali babool, Khair, Ber and Khijado. Whereas, the fruit orchards dominate in the area. Due to favourable climatic condition, tree cover was found very good. The result showed that population of exotic species was increasing in this region. Furthermore, the Eucalyptus sp., Bangali babool, Casuarina and Subabool combined four species had share of over one fourth in the total population of trees in South Gujarat. Rizvi et al., (2016) reported four prevalent agroforestry systems in Gujarat state viz.; agrisilviculture, agrihorticulture, silvihorticulture and boundary plantation in Gujarat plains and hills. Further, various tree species grown under agroforestry system were Mangifera indica (Mango), Manilkara zapota (Sapota), Zizyphus mauritiana (Ber), Ailanthus excelsa (Arsadu), Tectona grandis (Teak) and Azadirachta indica (Neem).

Singh (2017) observed that about $71.3 \%$ of the TOF particularly agroforestry was on private land (which includes farmland and orchards). It was observed that the plantations of Casuriana and Bengali babool were increasing in the high rainfall areas of south Gujarat, although teak, khair and bamboo were also preferred by the farmers. Further, among the fruit species, Mango, Drum stick, Custard apple, Indian goose berry, Zizyphus sp., Jamun, Coconut, Sapota and Guava were recorded as important tree species raised by the farmers.

\section{Agroforestry systems and practices in South Gujarat}

Bhusara et al., (2016) reported three major agroforestry systems practiced by majority of farmers in Valsad district of South Gujarat viz.; agrisilviculture system, agrihorticulture system and hortipasture system. Whereas, the system type identified were teak+ sugarcane, teak + banana and teak + okra, mango + rice, mango + banana and mango + chilli and mango + maize and mango + sorghum. Panchal et al., (2017) found that the farmers were practicing four agroforestry systems in Navsari district of South Gujarat namely Agri-silvihorticultural systems (ASHS), Agrisilvicultural systems (ASS), Agrihorticultural systems (AHS) and Silvopastural systems (SPS). 
Table.1 Synoptic view of existing agroforestry systems reported by researchers in Gujarat particularly in South Gujarat

\begin{tabular}{|c|c|c|c|c|c|}
\hline Sr. No. & $\begin{array}{c}\text { Agroforestry systems and practices } \\
\text { reported }\end{array}$ & $\begin{array}{c}\text { No. of } \\
\text { agroforestry } \\
\text { systems and } \\
\text { practices reported }\end{array}$ & $\begin{array}{l}\text { Region/ } \\
\text { District }\end{array}$ & Agroclimatic zone & References \\
\hline 1. & $\begin{array}{l}\text { Horti-silvi (HS), } \\
\text { Agri-silvihorticulture (ASH), } \\
\text { Agri-silviculture (AS), } \\
\text { Agri-horticulture (AH), } \\
\text { Homegardens (HG) and } \\
\text { Horti-pasture (HP) }\end{array}$ & 6 & South Gujarat & $\begin{array}{l}\text { South Gujarat zone }-\mathrm{I} \text { with heavy } \\
\text { rainfall }(1500 \mathrm{~mm} \text { to } 2500 \mathrm{~mm}) \text { and } \\
\text { hilly areas }\end{array}$ & $\begin{array}{l}\text { Dobriyal et al., } \\
(2019)\end{array}$ \\
\hline 2. & Peripheral planting and Mixed planting & 2 & Gujarat & Agroclimatic zone in Gujarat state & Verma (1991) \\
\hline 3. & $\begin{array}{l}\text { Agrisilviculture system, } \\
\text { Agrihorticulture system and } \\
\text { Hortipasture system }\end{array}$ & 3 & $\begin{array}{l}\text { Valsad district- } \\
\text { South Gujarat }\end{array}$ & $\begin{array}{l}\text { South Gujarat zone - II with medium } \\
\text { rainfall }(1000 \mathrm{~mm} \text { to } 1500 \mathrm{~mm})\end{array}$ & $\begin{array}{l}\text { Bhusara et al., } \\
(2016)\end{array}$ \\
\hline 4. & $\begin{array}{l}\text { Agrisilviculture, } \\
\text { Agrihorticulture, } \\
\text { Silvihorticulture and Boundary plantation }\end{array}$ & 4 & $\begin{array}{l}\text { Gujarat plains } \\
\text { and hills }\end{array}$ & $\begin{array}{l}\text { Agroclimatic zone in Gujarat state } \\
\text { and South Gujarat zone - II with } \\
\text { medium rainfall }(1000 \mathrm{~mm} \text { to } 1500 \\
\mathrm{mm})\end{array}$ & Rizvi et al., (2016) \\
\hline 5. & $\begin{array}{l}\text { Agri-silvihorticultural systems (ASHS) } \\
\text { Agrisilvicultural systems (ASS), } \\
\text { Agri-horticultural systems (AHS) and } \\
\text { Silvopastural systems (SPS) }\end{array}$ & 4 & $\begin{array}{l}\text { Navsari } \\
\text { District, South } \\
\text { Gujarat }\end{array}$ & $\begin{array}{l}\text { South Gujarat zone }-\mathrm{I} \text { with heavy } \\
\text { rainfall }(1500 \mathrm{~mm} \text { to } 2500 \mathrm{~mm}) \text { and } \\
\text { hilly areas }\end{array}$ & $\begin{array}{l}\text { Panchal et al., } \\
(2017)\end{array}$ \\
\hline 6. & $\begin{array}{l}\text { Agri-silvi-horticulture (ASH), } \\
\text { Agri-silviculture (AS), } \\
\text { Agri-horticulture (AH), } \\
\text { Homegardens (HG) and } \\
\text { Horti-pasture (HP) }\end{array}$ & 5 & $\begin{array}{l}\text { Navsari } \\
\text { District, South } \\
\text { Gujarat }\end{array}$ & $\begin{array}{l}\text { South Gujarat zone }-\mathrm{I} \text { with heavy } \\
\text { rainfall }(1500 \mathrm{~mm} \text { to } 2500 \mathrm{~mm}) \text { and } \\
\text { hilly areas }\end{array}$ & Singh et al., (2017) \\
\hline 7. & $\begin{array}{l}\text { Horti-silvi (HS), } \\
\text { Agri-silvihorticulture (ASH), } \\
\text { Agri-silviculture (AS), } \\
\text { Agri-horticulture (AH), } \\
\text { Homegardens (HG) and } \\
\text { Horti-pasture (HP) }\end{array}$ & 6 & South Gujarat & $\begin{array}{l}\text { South Gujarat zone }-\mathrm{I} \text { with heavy } \\
\text { rainfall }(1500 \mathrm{~mm} \text { to } 2500 \mathrm{~mm}) \text { and } \\
\text { hilly areas }\end{array}$ & $\begin{array}{l}\text { Dobriyal et al., } \\
(2019)\end{array}$ \\
\hline
\end{tabular}

Source: Secondary 
The components of agroforestry systems were recorded under AHS Mango + Sapota + Lemon + Coriander, Mango + Cabbage, Mango + Rice, whereas under ASS representing two system types i.e. Teak + Sugarcane and Eucalyptus + Spider lily. ASHS and SPS had only one system type i.e. Mango + Teak + Brinjal and Sapota + grass, respectively. Besides these ASS was represented by two more system types (Teak + Rice and Arjun + Nagali). Singh et al., (2017) revealed that the farmers prominently adopted five types of agroforestry systems according to the household requirement and livelihood security i.e. Agri-silvi-horticulture (ASH), Agri-silviculture (AS), Agrihorticulture (AH), Homegardens (HG) and Horti-pasture (HP). The components of agroforestry systems recorded were mango + rice, sugarcane + teak, vegetable crops + mango+ teak, sapota + grass. Whereas in the hilly track of study area had Eleusine coracana + teak (boundary plantation), rice + Terminalia tomentosa and Eleusine coracana + Terminalia tomentosa. Dobriyal et al., (2019) reported six agroforestry systems most of the farmers of the region are practicing namely Horti-silvi (HS), Agrisilvihorticulture (ASH), Agri-silviculture (AS), Agri-horticulture (AH), Homegardens (HG) and Horti-pasture (HP) systems at their fields.

In conclusion based on nature of the components, household requirements and livelihood security minimum two agroforestry systems namely Peripheral and mixed planting and maximum six agroforestry systems namely Horti-silvi (HS), Agrisilvihorticulture (ASH), Agri-silviculture (AS), Agri-horticulture (AH), Homegardens (HG) and Horti-pasture (HP) were reported, which were adopted by farmers in Gujarat as well as South Gujarat. Nowadays, the area under agroforestry is increasing in the region, hence their wide scope to for the improvement of the agroforestry systems and promotion of he need based agroforestry systems in the region.

\section{References}

Bhatt, G.D.; Kushwaha, S.P.S.; Nandyl, S. and Bargali, K. (2013). Vegetation types and land uses mapping in South Gujarat using remote sensing and geographic information system. International Journal of Advancement in Remote Sensing, GIS and Geography, 1 (1): 20-31.

Bhusara, J.B.; Thakur, N.S. and Hegde, H.T. (2016). Biological yield and carbon sequestration in prominent traditional agroforestry systems in Valsad district, Gujarat, India. Indian Journal of Ecology, 43 (Special Issue-1): 318322.

Cooper, P.; Leakey, R.R.; Rao, M. and Reynolds, L. (1996). Agroforestry and the mitigation of land degradation in the humid and sub-humid tropics of Africa. Experimental Agriculture, 32 (3): 235-290.

Dhyani,S.K. (2013). Agroforestry in Indian Perspective. In: Agroforestry Opportunities for Enhancing Resilience to Climate Change in Rainfed Areas. (Eds) G Rajeshwar Rao M Prabhakar G Venkatesh I Srinivas K Sammi Reddy. ICAR - Central Research Institute for Dryland Agriculture National Innovations in Climate Resilient Agriculture Hyderabad - 500 059, India. p12-28.

Dobriyal, M.J; Husain, M; Prajapati, V.M and Jilariya, D. (2019). Agroforestry models of South Gujarat. Flora and Fauna, 25(2): 137-139.

Dwivedi, (1999). Agroforestry : principles and practices. Oxford and IBH publication Co. Pvt. Ltd., New Delhi, $365 \mathrm{p}$. 
ISFR (2019). India State Forest Report. Forest Survey of India (Ministry of Environment and Forests and Climate Change), Dehradun, India.

Jharna Pathak. (2011). Agroforestry in tribal areas of Gujarat: Move towards sustainable agriculture? GIDR working paper series no. 203. Gujarat Institute of Development Research, Ahmedabad, 43p.

Lundgren, B.O. (1982). Cited in Editorial: What is agroforestry? Agroforestry Systems., 1: 7-12.

NAFP (2014). National Agroforestry Policy, 2014, Department of Agriculture \& Cooperation, Ministry of Agriculture, Government of India, New Delhi.

Nair, P.K.R. (1985). Classification of agroforestry systems. Agroforestry systems, 3:92-128.

Nair, P.K.R. (1993). An introduction to agroforestry. Kluwer Academic Publishers, London in cooperation with International Centre for Research in Agroforestry.499p.

Panchal, J.S; Thakur, N.S.; Jha, S.K. and Vikas Kumar. (2017). Productivity and carbon sequestration under prevalent agroforestry systems in Navsari district, Gujarat, India. Int J Current Microbiology App. Sci., 6(9): 34053422.

Rizvi, R.H.; Newaj, R.; Prasad, R.; Handa, A.K.; Alam, B.;Chavan, S.B.; Saxena, A.; Karmakar, P.S.; Jain, A. and Chaturvedi, M. (2016). Assessment of carbon storage potential and area under agroforestry systems in Gujarat Plains by CO2FIX model and remote sensing techniques. Current science, 110 (10): $2005-2011$.

SFR (2013). State Forest Report. Forest Survey of India (Ministry of Environment and Forests and Climate Change), Dehradun, India.

Singh, H. S. (2013). Tree wealth in the nonforest areas of Gujarat. Trees Outside Forest (TOF) - Third Tree Counting2013. Gujarat Forest Department, Gandhinagar.

Singh, H.N (2017). Agro-forestry in Gujarat: an economic opportunity with environment enhancement. Gujarat Forest Department, Gandhinagar. (Viewed at https://forests.gujarat.gov.in/writeread data/images/pdf/7_Agro-Forestry-inGujarat.pdf )

Singh, N.R, Arunachalam, A. Bhusara, J.B., Dobriyal, M.J and Gunaga, R.P. (2017). Diversification of agroforestry systems in Navsari district of South Gujarat. Indian Journal of Hill Farming, 30(1): 70-72.

Verma, D.P.S. (1990). Agroforestry practices of Gujarat State. The International Tree Crops Journal, 6:17-30.

Verma, D.P.S. (1991). Evaluation of agroforestry practices I Gujarat State, India. Forest Ecology and Management, 1(1-4): 325-335.

\section{How to cite this article:}

Deshmukh, H. K., M. B. Tandel, R. P. Gunaga, N. S. Thakur, M. J. Dobriyal, Narendra Singh, H. N. Chhatrola and Mevada, R. J. 2020. Three Decades of Review on Existing Agroforestry Systems and Practices in South Gujarat. Int.J.Curr.Microbiol.App.Sci. 9(08): 2973-2978. doi: https://doi.org/10.20546/ijcmas.2020.908.334 